Jurnal Mahasiswa BK An-Nur : Berbeda, Bermakna, Mulia

Volume 7 Nomor 3 Tahun 2021

Tersedia Online: https://ojs.uniska-bjm.ac.id/index.php/AN-NUR

p-ISSN. 2460-9722 | e-ISSN. 2622-8297

\title{
GAMBARAN PSYCHOLOGICAL WELL-BEING MAHASISWA SELAMA PROSES PERKULIAHAN ONLINE GUNA UNTUK MELIHAT LEARNING LOSS DI UNIVERSITAS BORNEO TARAKAN
}

\author{
Cici Ismuniar ${ }^{1}$, Emmy Ardiwinata ${ }^{2}$ \\ ${ }^{1,2}$ Program Studi Bimbingan dan Konseling, Fakultas Keguruan dan Ilmu Pendidikan, Universitas \\ Borneo Tarakan \\ Ciciismuniarubt@gmail.com/ 082232142444
}

\begin{abstract}
ABSTRAK
Psychological well being merupakan salah satu keadaan psikologis yang dialami oleh mahasiswa yang mempengaruhi pembelajarannya terutama disaat mewabahnya virus corona baru (COVID 19). Tujuan penelitian ini untuk mengetahui Psychological well being mahasiswa dalam menjalani kuliah daring. Penelitian ini menggunakan metode penelitian kuantitatif deskriptif dan skala penelitian ini menggunakan teori PWB (Psychological Well-Being) yang dikembangkan oleh Carol Ryff (1989). Skala PWB (Psychological WellBeing) yang di gunakan terdiri atas enam aspek yaitu otonomi, penguasaan atas lingkungan, pertumbuhan pribadi, hubungan positif dengan orang lain, tujuan hidup, dan penerimaan diri. Responden dalam penelitian ini merupakan Mahasiswa semester III dan IV Universitas Borneo Tarakan. Pemilihan sampel penelitian menggunakan Teknik simple random sampling sehingga respon pada penlitian ini sebanyak 250 mahasiswa. Hasil penelitian adalah Psychological well being mahasiswa Universitas Borneo Tarakan termasuk dalam kategori sedang, psychological well being mahasiswa berada di kategori sedang dimana artinya mahasiswa Universitas Borneo Tarakan cukup memiliki kesejahteraan psikologis atau Psychological Well-Being selama perkuliahan daring saat pandemic Covid-19. Namun di satu sisi selama pandemic proses pembelajaran daring/online, mahasiswa banyak mengalami kesulitan. Adanya kesulitan-kesulitan dalam proses pembelajaran ini akan mengakibatkan munculnya Learning loss.
\end{abstract}

Kata kunci : Kesejahteraan Psikologi, mahasiswa, learning loss

\begin{abstract}
Psychological well-being is one of the psychological conditions experienced by university students that affects their learning, particularly during the outbreak of the novel coronavirus diseases (COVID-19). This study aims to investigate psychological well-being of university students in online learning. This study used descriptive quantitative and PWB (Psychological Well-Being) scale developed by Carol Ryff (1989). The PWB (Psychological Well-Being) scale incorporates six aspects, namely autonomy, environmental mastery, personal growth, positive relations with others, purpose in life, and self-acceptance. The respondents comprised III and IV university students at Borneo Tarakan University. A sample of 250 university students was selected by using a simple random sampling technique. The findings show that psychological well-being of university students at Borneo Tarakan University was in the medium category which means they have sufficient psychological wellbeing in the online learning during the COVID-19 pandemic. However, many students may experience problems in the online learning during pandemic. These problems will cause learning loss on the learning process.
\end{abstract}

Keywords : Psychological well-being, university student, learning loss

Dipublikasikan Oleh :

UPT Publikasi dan Pengelolaan Jurnal

Universitas Islam Kalimantan Muhammad Arsyad Al-Banjari Banjarmasin 


\section{Cici Ismuniar ${ }^{1}$, Emmy Ardiwinata $^{2}$ \\ Jurnal Mahasiswa BK An-Nur : Berbeda, Bermakna, Mulia \\ Volume 7 Nomor 3 Tahun 2021 \\ Tersedia Online: https://ojs.uniska-bjm.ac.id/index.php/AN-NUR p-ISSN. 2460-9722 | e-ISSN. 2622-8297}

\section{PENDAHULUAN}

Pendahuluan harus berisi (secara berurutan) latar Pada awal tahun 2020 ini dunia dikejutkan dengan adanya wabah virus corona (Covid-19) yang menginfeksi hampir seluruh negara di dunia. Terhitung mulai tanggal 19 Maret 2020 sebanyak 214.894 orang terinfeksi virus corona, 8.732 orang meninggal dunia dan pasien yang telah sembuh sebanyak 83.313 orang. Khusus di Indonesia sendiri Pemerintah telah mengeluarkan status darurat bencana terhitung mulai tanggal 29 Februari 2020 hingga 29 Mei 2020 terkait pandemi virus ini dengan jumlah waktu 91 hari.

Langkah-langkah telah dilakukan oleh pemerintah untuk dapat menyelesaikan kasus luar biasa ini, salah satunya adalah dengan mensosialisasikan gerakan Social Distancing. Penyebaran virus yang sangat berbahaya ini. Salah satu lembaga pemerintahan yang langsung menanggapi kasus tersebut yaitu Kementrian Pendidikan dan Kebudayaan Republik Indonesia. Melalui surat edaran Menteri Pendidikan dan Kebudayaan Nomor 4 Tahun 2020 tentang pelaksanaan kebijakan pendidikan dalam masa darurat penyebaran Coronavirus Disease (Covid-19) dilaksanakan dengan cara belajar dari rumah yang diistilahkan dengan Perkuliahan online atau yang biasa disebut daring merupakan salah satu bentuk pemanfaatan internet yang dapat meningkatkan peran mahasiswa dalam proses pembelajaran.

Selama pembelajaran secara daring berbagai kendala ditemukan di lapangan, seperti: jaringan, fasilitas dan kapasitas android/Hp yang dimiliki oleh mahasiswa yang tidak memadai, maupun keterbatasan pembelian paket internet baik oleh pengajar maupun orang tua mahasiswa. Tidak sedikit mahasiswa mengeluhkan dalam belajar, tugas anak anak yang dianggap lebih banyak daripada hari-hari sebelumnya, maupun sulitnya akses jaringan di daerah tempat tinggal anak anak yang menyebabkan mereka harus mencari akses jaringan dengan mendaki gunung atau memanjat pohon.

Pada bulan April 2020, Northwest Evaluation Association (NWEA) merilis laporan yang mengikuti lintasan kerugian belajar berdasarkan kelas sejak awal pandemic. Bisa di lihat kurang nya inisiatif dan usaha mahasiswa selama mengikuti kuliah online di lakukan, Tidak dapat dipungkiri bahwa jika semua siswa kembali ke sekolah setelah istirahat panjang bisa saja pengetahuan dan keterampilan yang sebelumnya telah dipelajari hilang atau disebut dengan learning loss. Seperti penelitian yang dilakukan oleh JRC European Commission penerapan pembelajaran jarak jauh adalah kunci untuk memastikan kelangsungan pendidikan setelah penutupan fisik sekolah, siswa rata-rata kemungkinan akan mengalami kerugian belajar selama lockdown.

Learning loss merupakan suatu kondisi pada anak yang muncul karena adanya kesulitan-kesulitan dalam proses pembelajaran (Dziuban et al., 2018). mahasiswa yang mampu menakar kekuatannya secara akurat dalam menyelesaikan tugas atau masalah maka semakin mudah dirinya merasa sejahtera dalam hidupnya. Sebaliknya, mahasiswa yang tidak mampu menakar secara akurat kekuatannya maka tidak mudah merasa sejahtera. Kesejahteraan psikologis adalah sebuah keadaan seseorang yang mampu menerima dirinya apa adanya, mampu membentuk hubungan yang hangat dengan orang lain, memiliki kemandirian terhadap tekanan sosial, mampu mengontrol lingkungan eksternal, memiliki arti dalam hidup serta mampu merealisasikan potensi dirinya secara berkelanjutan..

Psychological well being dapat membantu individu untuk menumbuhkan emosi positif, merasakan kepuasan hidup dan kebahagiaan, mengurangi kecenderungan mereka untuk berperilaku negatif, dapat mengendalikan emosi dengan mudah (Fadhillah, 2016). Individu yang memiliki psychological well being yang tinggi adalah individu yang merasa puas dengan hidupnya, kondisi emosional yang positif, mampu melalui pengalamanpengalaman buruk yang dapat menghasilkan kondisi emosional negatif, memiliki hubungan yang positif dengan orang lain, mampu menentukan nasibnya sendiri tanpa bergantung dengan orang lain, mengon trol kondisi lingkungan sekitar, memiliki tujuan hidup yang jelas, dan mampu mengembangkan dirinya sendiri (Ryff, 1989) Adanya masalah tersebut mendorong kami melakukan sebuah penelitian yang bertujuan mengetahui gambaran psychological well being mahasiswa selama proses perkuliahan online di Universitas Borneo Tarakan guna untuk mencegah learning Ioss.

\section{METODE}

Tipe penelitian ini menggunakan pendekatan kuantitatif yang sifatnya deskriptif yang memiliki tujuan untuk menggambarkan fenomena yang terjadi (Sugiyono, 2019). Deskriptif kuantitatif adalah suatu metode penelitian yang menggambarkan dan menjelaskan variabel-variabel independen untuk dianalisis pengaruhnya terhadap variabel dependen (Sugiyono, 2018). Populasi dalam penelitian ini adalah mahasiswa semester III dan IV Universitas Borneo Tarakan. Alat ukur yang digunakan dalam penelitian ini yaitu PWB (Psychological Well-Being) yang dikembangkan oleh Carol Ryff (1989) yang merupakan alat ukur psikologis yang terdiri atas enam aspek yang diukur yakni otonomi, penguasaan atas 
Cici Ismuniar ${ }^{1}$, Emmy Ardiwinata $^{2}$

Jurnal Mahasiswa BK An-Nur : Berbeda, Bermakna, Mulia

Volume 7 Nomor 3 Tahun 2021

Tersedia Online: https://ojs.uniska-bjm.ac.id/index.php/AN-NUR p-ISSN. 2460-9722 | e-ISSN. 2622-8297

lingkungan, pertumbuhan pribadi, hubungan positif dengan orang lain, tujuan hidup, dan penerimaan diri. Skala ini berbentuk skala likert yang terdiri dari empat pilihan jawaban.

\section{HASIL DAN PEMBAHASAN}

Berdasarkan hasil perhitungan menggunakan Software SPSS, diperoleh Skor Psychological WellBeing paling banyak termasuk ke dalam kategori sedang sebanyak $74,4 \%$. Data hasil penelitian telah dipaparkan pada tabel 1 .

Tabel 1. Kelompok Skor Psychological well being

\begin{tabular}{|c|c|c|c|}
\hline Kategori & $\mathbf{X}$ & Frequancy & Percent (\%) \\
\hline Kurang & $X<61,864$ & 31 & 12,4 \\
\hline Sedang & $61,864 \leq X<78,076$ & 186 & 74,4 \\
\hline Tinggi & $X \geq 78,076$ & 33 & 13,2 \\
\hline \multicolumn{2}{|c|}{ Total } & 250 & 100,0 \\
\hline
\end{tabular}

Keterangan: Data kelompok Psychological Well-Being

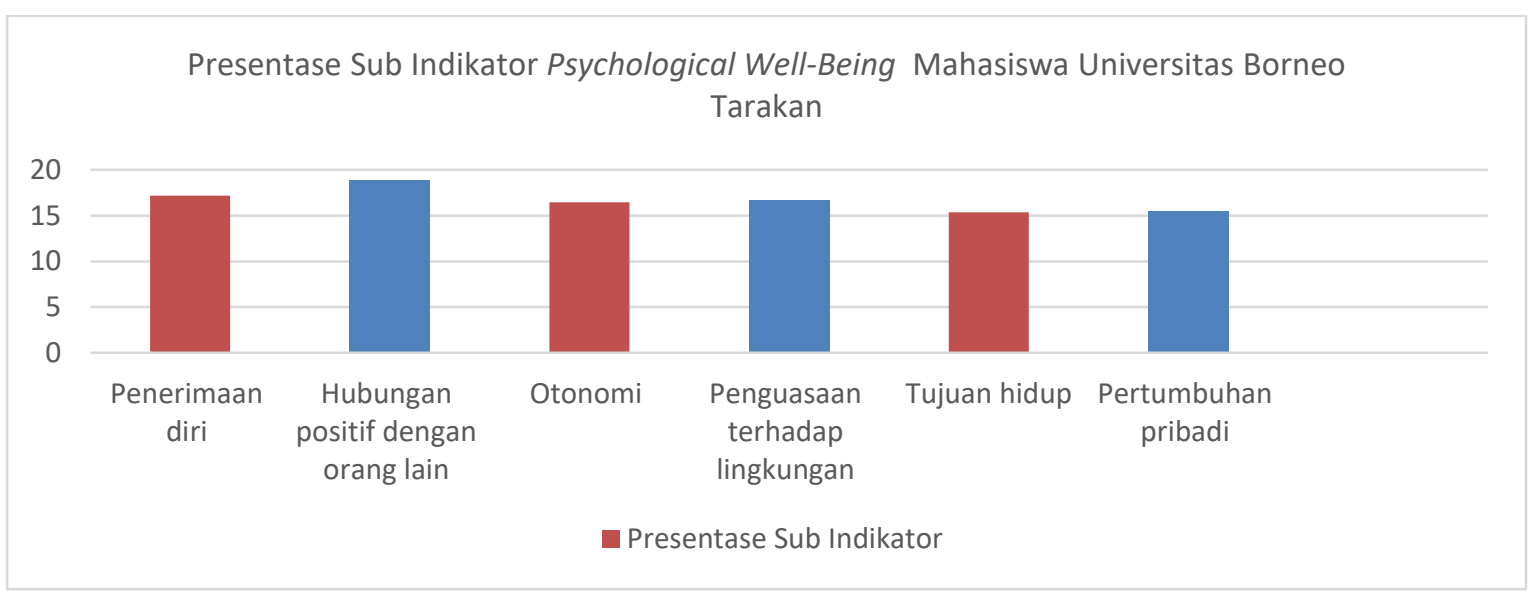

Gambar 1. Indikator Dominan Pada Aspek Psychological well being

Sub Indicator Psychological Well-Being kategori tertinggi pada mahasiswa Universitas Borneo pada penelitian ini ada di sub indicator ke dua yaitu hubungan positif dengan orang lain dan kategori rendah ada di tujuan hidup, dapat dilihat pada gambar 1.

\section{PEMBAHASAN}

Berdasarkan hasil analisis data yang telah dilakukan, dapat diketahui bahwa Psychological WellBeing di Universitas Borneo Tarakan terbagi menjadi 3 (tiga) kategori. Pertama kategori Psychological responden, berarti kesejahteraan psikologisnya semakin baik. Begitu pula, skor PWB yang rendah Mahasiswa Universitas Borneo Tarakan termasuk dalam kategori sedang, dimana artinya mahasiswa Universitas Borneo Tarakan cukup
Well-Being tinggi dimana pada penelitian ini memiliki presentase $12,4 \%$ dengan jumlah 31 mahasiswa, tingkat Psychological Well-Being sedang 74,4\% dengan jumlah 186 mahasiswa, dan tingkat Psychological Well-Being mahasiswa rendah 13,2\% dengan 33 mahasiswa. Skala PWB pada penelitian ini dikembangkan oleh Carol D. Ryff (1989) dimana tujuannya untuk mengukur kesejahteraan dan kebahagiaan yang meliputi enam aspek, yaitu otonomi, penguasaan lingkungan, pertumbuhan pribadi, hubungan positif dengan orang lain, tujuan hidup, dan penerimaan diri. Semakin tinggi skor PWB menunjukkan bahwa kesejahteraan psikologisnya juga buruk. Dari hasil penelitian memiliki kesejahteraan psikologis atau Psychological Well-Being selama perkuliahan daring saat pandemic Covid-19 dan Psychological Well-Being merupakan 


\section{Cici Ismuniar ${ }^{1}$, Emmy Ardiwinata $^{2}$ \\ Jurnal Mahasiswa BK An-Nur : Berbeda, Bermakna, Mulia \\ Volume 7 Nomor 3 Tahun 2021 \\ Tersedia Online: https://ojs.uniska-bjm.ac.id/index.php/AN-NUR p-ISSN. 2460-9722 | e-ISSN. 2622-8297}

suatu kondisi individu yang sejahtera secara psikologis dimana keadaan individu tersebut ditandai dengan mampu menerima dirinya apa adanya, mampu membentuk hubungan yang hangat dengan orang lain.

Gambaran Psychological Well-Being mahasiswa Universitas Borneo Tarakan termasuk dalam kategori sedang sejumlah 186 mahasiswa, dimana kemungkinan selama pandemic Covid 19 mereka cukup memiliki sikap positif terhadap diri sendiri, mengakui dan menerima berbagai aspek diri termasuk kualitas baik dan buruk, dan merasa positif tentang kehidupan yang telah dijalani, selain itu mahasiswa Universitas Borneo Tarakan walaupun belajar secara daring mereka cukup mempunyai hubungan yang hangat, saling percaya dengan orang lain, memperhatikan kesejahteraan orang lain, dan mampu melakukan empati yang kuat contoh nya para mahasiswa masih sering memberikan dukungan secara moril dan materi walaupun secara online kepada masyarakat yang tertimpa musibah di Provinsi Kalimantan Utara. Adanya Covid-19 ini membuat 186 mahasiswa Universitas Borneo Tarakan cukup mampu mengarahkan diri dan mandiri, mampu menghadapi tekanan sosial, mengatur tingkah laku sendiri dan mengevaluasi diri dengan standar pribadi. Walaupun BDR mahasiswa mampu mengatur lingkungan, mengontrol berbagai kegiatan eksternal yang kompleks, dan menggunakan kesempatan yang ada secara efektif. Jika dilihat dari indicator purpose in life 186 mahasiswa Universitas Borneo Tarakan bahwa individu cukup mempunyai tujuan dan arah hidup, merasakan adanya arti / makna dalam hidup masa kini dan masa lampau. Individu yang berfungsi secara positif memiliki tujuan, misi, dan arah yang mebuatnya merasa hidup ini memiliki makna. Serta selama pandemic Covid 19 mahasiswa cukup merasakan adanya pengembangan potensi diri yang berkelanjutan, terbuka terhadap pengalamanpengalaman baru, menyadari potensi diri, dan dapat melihat kemajuan diri dari waktu ke waktu, seperti para mahasiswa dapat menimba ilmu bukan hanya dari perkuliahan melainkan mahasiswa dapat mengikuti webinar yang dilaksanakan jurusan/fakultas Universitas Borneo Tarakan dengan Universitas lainnya

Berdasarkan indikator atau aspek aspek PWB tampak bahwa Hubungan positif dengan orang lain merupakan aspek yang paling dominan atau yang berperan penting pada mahasiswa Universitas Borneo Tarakan, dilanjutkan dengan indicator penerimaan diri, kemampuan penguasaan lingkungan. Otonomy, Pertumbuhan Pribadi dan terendah di indicator Tujuan hidup. Jika dilihat indicator atau aspek Hubungan Positif dengan orang lain lebih dominan, kemungkinan para mahasiswa selama pandemic lebih mempunyai hubungan yang hangat, saling percaya dengan orang lain, memperhatikan kesejahteraan orang lain, dan mampu melakukan empati yang kuat walaupun hanya secara online. Seperti dengan adanya waktu yang banyak dirumah, membuat para mahasiswa memiliki hubungan positif dengan keluarga, saudara dan tetangga maupun orang lain yang mungkin bisa dilakukan secara online. Namun, walaupun para mahasiswa mampu menjalin hubungan dengan orang lain selama pandemic Covid 19 membuat mereka kurang mempunyai arti hidup, tujuan, arah hidup dan cita-cita yang jelas, serta tidak melihat adanya tujuan dari kehidupan masa lalu. Mahasiswa mungkin belum memahami tujuan hidupnya, belum memahami arah hidup, belum mampu mengambil makna dari kondisi saat ini dan keputusan kedepannya. Seperti saat ini banyak mahasiswa Universitas Borneo Tarakan yang membantu orang tua bekerja di sawah dan warung dibandingkan melakukan perkuliahan secara daring.

Jika dilihat dari gambaran PWB dan hasil sub indikator terendah dimana yang terendah adalah purpose in life atau tujuan hidup, dimana pada indikator ini saat pandemic covid-19 para mahasiswa kurang mempunyai arti hidup, tujuan, arah hidup dan cita-cita yang jelas, serta tidak melihat adanya tujuan dari kehidupan masa lalu. Kesejahteraan Psikologis/ Psychological well being adalah situasi psikologis seseorang yang berfungsi secara baik dan positif (Ramadhani et al., 2016). Kesejahteraan psikologis ialah hal yang penting bagi setiap individu dan berlaku bagi semua kalangan, termasuk kalangan remaja dewasa atau mahasiswa sekalipun. Menurut Siswoyo (2007) mahasiswa dapat didefinisikan sebagai individu yang sedang menuntut ilmu ditingkat perguruan tinggi, baik negeri maupun swasta atau lembaga lain yang setingkat dengan perguruan tinggi. Mahasiswa dinilai memiliki tingkat intelektualitas yang tinggi, kecerdasan dalam berpikir dan kerencanaan dalam bertindak. Berpikir kritis dan bertindak dengan cepat dan tepat merupakan sifat yang cenderung melekat pada diri setiap mahasiswa, yang merupakan prinsip yang saling melengkapi.

Pandemi Covid-19 telah memaksa 1,7 miliar siswa melakukan pembelajaran jarak jauh (PJJ) akibat sekolah-sekolah ditutup. Hal ini membuat berbagai jenjang pendidikan mencoba mencari metode pembelajaran yang tepat, meskipun hingga saat ini PJJ telah menghasilkan kerugian besar dalam pembelajaran (Donnelly \& Patrinos, 2021; Engzell et al., 2021). Bagi mahasiswa, kesulitan pertama adalah berubahnya iklim pembelajaran yang biasanya dilaksanakan secara langsung dan secara komunal menjadi pembelajaran yang dilakukan secara individu. Siswa yang biasanya berinteraksi langsung dengan 


\section{Cici Ismuniar ${ }^{1}$, Emmy Ardiwinata $^{2}$ \\ Jurnal Mahasiswa BK An-Nur : Berbeda, Bermakna, Mulia \\ Volume 7 Nomor 3 Tahun 2021 \\ Tersedia Online: https://ojs.uniska-bjm.ac.id/index.php/AN-NUR p-ISSN. 2460-9722 | e-ISSN. 2622-8297}

guru dan siswa lain, kini tidak ada interaksi social yang terjadi saat proses pembelajaran. Menurut penelitian (Puspitorini, 2020) selama pandemik, banyak sekali kesulitan-kesulitan belajar yang dialami oleh siswa dan guru. Untuk guru sendiri, kesulitan dalam melaksanakan proses pembelajaran adalah pada aspek sarana pendidikan. Jaringan internet merupakan salah satu sarana pembelajaran yang wajib dimiliki oleh guru selama pembelajaran jarak jauh (PJJ). Adanya kesulitan-kesulitan dalam proses pembelajaran ini akan mengakibatkan munculnya Learning loss (Donnelly \& Patrinos, 2021; Engzell et al., 2021; Kashyap et al., 2021; Li et al., 2020; Yadav, 2021; Zakharova et al., 2021). Learning loss merupakan salah satu konsep yang didefinisikan sebagai adanya ketidakmaksimalnya proses pembelajaran yang dilaksanakan di sekolah (Kashyap et al., 2021; Li et al., 2020). Tidak maksimalnya

\section{PENUTUP}

Kesimpulan

Berdasarkan hasil penelitian yang dilakukan di Universitas Borneo Tarakan, rata-rata kesejahteraan psikologi atau psychological well being mahasiswa berada di kategori sedang dimana artinya mahasiswa Universitas Borneo Tarakan cukup memiliki kesejahteraan psikologis atau Psychological WellBeing selama perkuliahan daring saat pandemic Covid-19. Namun di satu sisi selama pandemic proses pembelajaran daring/online, mahasiswa banyak mengalami kesulitan. Adanya kesulitan-kesulitan dalam proses pembelajaran ini akan mengakibatkan munculnya Learning loss. Dengan demikian, Learning loss akan dapat berdampak pada kualitas sumber daya manusia yang akan lahir di tahun-tahun selama pandemic Covid-19 ini. Permasalahan ini dapat berpengaruh terhadap kesejahteraan psikologis yang dimiliki mahasiswa tersebut. Hal ini dikarenakan Psychological well being sangat mempengaruhi perilaku ataupun kebiasaan, dan umumnya pendidik yang mengajar disekolah adalah orang yang turut ambil bagian dalam pencapaian Psychological well being bagi siswa (Sitinjak, 2015). Saran

Selama pandemic covid-19 khusus jurusan bimbingan dan konseling di fakultas FKIP Universitas Borneo Tarakan memanfaatkan para konselor untuk membuka layanan konseling online tujuannya agar para mahasiswa dapat melakukan konsultasi permasalahan yang sedang di hadapinya baik permasalahan selama pembelajaran daring maupun permasalahan individu itu sendiri. Selain itu para pengajar dan Universitas perlu memberi perhatian terhadap kesejahteraan psikologis pelajar dengan cara Universitas perlu menyusun program proses pembelajaran, akan berakibat pada hasil informasi yang didapatkan siswa dan hasil belajar siswa yang juga tidak maksimal. Dengan demikian, Learning loss akan dapat berdampak pada kualitas sumber daya manusia yang akan lahir di tahun-tahun selama pandemic Covid-19 ini. Permasalahan ini dapat berpengaruh terhadap kesejahteraan psikologis yang dimiliki mahasiswa tersebut. Tingginya tingkat Psychological well being yang dimiliki oleh pelajar dapat menimbulkan dampak baik seperti perasaan positif, begitu juga sebaliknya tingkat Psychological well being yang rendah dapat menimbulkan perasaan negatif terhadap dirinya. Hal ini dikarenakan Psychological well being sangat mempengaruhi perilaku ataupun kebiasaan, dan umumnya pendidik yang mengajar disekolah adalah orang yang turut ambil bagian dalam pencapaian Psychological well being bagi siswa (Sitinjak, 2015). untuk mempromosikan kesehatan mental dan emosional, terutama terkait dengan kondisi pandemi COVID-19. Dalam hal ini, konselor/dosen bimbingan konseling dapat menjadi pemimpin yang memandu peran setiap warga sekolah dan menyusun strategi pendampingan bagi guru dan siswa yang memerlukan dukungan psikologis dalam pembelajaran, termasuk memberikan edukasi kepada orang tua dalam mengatasi potensi hambatan psikologis siswa yang mungkin muncul saat mendampingi selama BDR.

\section{REFERENSI}

Carr, A. (2004). Positive psychology: The science of happiness and human $s$ trength. New York: Brunner Routledge

Diener, E., Horwitz, J., \& Emmons, R. A. (1984). The Satisfaction with Life Scale. Journal of Personality Assessment.

Di Pietro, G. (2020). JRC TECHNICAL REPORT. The likely impact of COVID- 19 on education: Reflections based on the existing literature and recent international datasets.

Donnelly, R., \& Patrinos, H. A. (2021). Learning Loss During Covid-19: An Early Systematic Review. Covid Economics Vetted and RealTime Papers, 77.

Dziuban, C., Graham, C. R., Moskal, P. D., Norberg, A., \& Sicilia, N. (2018). Blended Learning: The New Normal And Emerging Technologies. International Journal Of Educational Technology In Higher Education, 15(1), 1-16. Https://Doi.Org/10.1186/S41239-017-0087-5

Engzell, P., Frey, A., \& Verhagen, M. D. (2021). Learning Loss Due to School Closures During the Covid-19 Pandemic. Proceedings of the National Academy of Sciences of the 
Cici Ismuniar ${ }^{1}$, Emmy Ardiwinata $^{2}$

Jurnal Mahasiswa BK An-Nur : Berbeda, Bermakna, Mulia

Volume 7 Nomor 3 Tahun 2021

Tersedia Online: https://ojs.uniska-bjm.ac.id/index.php/AN-NUR p-ISSN. 2460-9722 | e-ISSN. 2622-8297

United States of America, 118(17). https://doi.org/10.1073/PNAS.2022376118

Huang, Y., Wang, Y., Tai, Y., Liu, X., Shen, P., Li, S., ... Huang, F. (2020). Curricularface:

Adaptive Curriculum Learning Loss For

Deep Face Recognition. Proceedings Of

The Ieee Computer Society Conference On Computer Vision And Pattern Recognition. Https://Doi.Org/Retrieved From Https://Doi.Org/10.1109/Cvpr42600.2020.00 594.

Linawati, R. A., \& Desiningrum, D. R. (2017). Hubungan antara Religiusitas dengan Psychological Well-Being pada Siswa SMO Muhammadiyah 7 Semarang. Jurnal Empati, 7(3), 105-109. Retrieved from https://ejournal3.undip.ac.id/index.php/empat i/article/view/19738

Maulyda, M. A., Erfan, M., \& Hidayati, V. R. (2021). Analisis Situasi Pembelajaran Selama Pandemi Covid- 19 Di Sdn Senurus: Kemungkinan Terjadinya Learning Loss. Closse, 4(3), 328-336.

Puspitorini, F. (2020). Strategi Pembelajaran Di Perguruan Tinggi Pada Masa Pandemi Covid-19. Jurnal Kajian Ilmiah, 1(1). https://doi.org/10.31599/jki.v1i1.274

Ramadhani, T., Djunaedi, D., \& Sismiati S., A. (2016). Kesejahteraan Psikologis (Psychological Well-Being) Siswa yang Orangtuanya Bercerai (Studi Deskriptif yang Dilakukan pada Siswa di SMK Negeri 26 Pembangunan Jakarta). Insight: Jurnal Bimbingan Konseling, 5(1), 108. https://doi.org/10.21009/insight.051.16

Ryff, C. D. (1989). Happiness is everything, or is it? Exploration on the meaning of psychological well- being. Journal of Personality and Social Psychology, 57, 6, 1069 - 1081

Seligman, M.E.P. (2005). Authen- tic happiness :Menciptakan keba- hagiaan dengan psikologi positif. Alih bahasa: Eva Yulia. Nukman. Bandung : PT MizanPustaka

Thoybah, N. (2020). Determinan Kesejahteraan Psikologis Siswa SMP di Kota Padang. (Skripsi, Jurusan Psikologi Fakultas Ilmu Pendidikan Universitas Negeri Padang).

Gladding, S. T. (2012). Konseling: Profesi yang Menyeluruh (6th ed.). (P. Winarno, \& L. Yuwono, Trans.) Jakarta: PT. Indeks. 